\title{
Pemanfaatan Sistem Informasi Dalam Penentuan Alokasi E-Budgeting Pada PT. Multipedia Teknika Indonesia
}

\author{
${ }^{1}$ Ilamsyah, ${ }^{2}$ Arief Saptono, ${ }^{3}$ Novi Rifkhah Prastiwi \\ ${ }^{1}$ ilamsyah@ raharja.info, ${ }^{2}$ arief.saptono@ raharja.info, ${ }^{3}$ novi.rifkhah@ raharja.info \\ ${ }^{1}$ Program Studi Sistem Komputer Universitas Raharja, ${ }^{2,3}$ Program Studi Sistem Informasi Universitas \\ Raharja.
}

\begin{abstract}
Abstrak
Sistem Informasi budgeting atau yang berhubungan dengan anggaran saat ini masih sangat dibutuhkan untuk mengatur pengeluaran yang dilakukan perusahaan. PTMultipedia Teknika Indonesia menggunakan sistem budgeting yang tergolongsemi-komputerisasi karena masih menggunakan Microsoft Excel. Proses pengajuandan penggunaan budget dirasa cukup rumit karena harus melalui banyak approvalmelalui surel sehingga rentan kesalahan serta lambat dalam prosesnya. Tujuandilakukannya penelitian ini adalah untuk mengetahui kelemahan yang ada padasistem budgeting PT Multipedia Teknika Indonesia yang berjalan saat ini dan merancang sebuah sistem e-budgeting dari permasalahan yang ada. Metode yang digunakan dalam pengumpulan data adalah observasi dengan melakukan pengamatan terhadap sistem yang berjalan, studi pustaka untuk memperoleh informasi dengan mempelajari buku maupun penelitian sejenis sebelumnya, dan wawancara untuk memperoleh informasi yang tepat atas pengguna yang berkaitan dengan proses tersebut. Metode analisis, perancangan dan pengujian yang digunakan adalah PIECES, UML dan Black Box Testing. Hasil yang diperoleh setelah melakukan penelitian adalah lambatnya proses approval saat pengajuan dan penggunaan budget serta proses pembuatan laporan akibat pengecekan berulang karena data yang selisih, sehingga dibutuhkan sistem yang memudahkan pengguna dalam proses pengajuan, penggunaan, maupun pembuatan laporan secara realtime.
\end{abstract}

Kata Kunci : budgeting, approval, laporan

\begin{abstract}
Information systems budgeting, or budgeting connected to the existing budget, is still required to control the company's spending. Because Microsoft Excel is still used, PT Multipedia Teknika Indonesia's budgeting system is classified as semicomputerized. The process of submitting and using the budget is deemed hard because it must go through multiple approvals via email, which makes it prone to errors and slow. The goal of this study is to identify the flaws in PT Multipedia Teknika Indonesia's present budgeting system and to create an e-budgeting system that addresses those flaws. The data collection method is observation, which involves monitoring the existing system, literature study, which involves studying books or past similar studies, and interviews, which involves gathering precise information on people involved in the process. PIECES, UML, and Black Box Testing are the analytical, design, and testing approaches employed. The delayed approval process when submitting and utilizing the budget, as well as the reporting process because of repetitive checks due to data discrepancies, were discovered as a result of the research, and a system that makes it easier for users to submit, use, and create reports in real time is required.
\end{abstract}

Key words : budgeting, approval, report 


\section{Pendahuluan}

Transparansi saat pengajuan dan penggunaan anggaran / budget pada sebuah perusahaan atau instansi sangat diperlukan untuk memonitoring keuangan yang ada. Pengajuan dan penggunaan budget dengan sistem semi-komputerisasi dapat memperlambat hingga mengurangi keakuratan data. Sistem Informasi budgeting atau yang berhubungan dengan pengajuan dan penggunaan anggaran sangat dibutuhkan saat ini untuk mengatur pengeluaran yang dilakukan oleh perusahaan. Dengan adanya sistem budgeting, pengeluaran dapat terkontrol dengan baik sehingga dana yang digunakan pun akan lebih efisien. PT Multipedia Teknika Indonesia merupakan perusahaan yang bergerak di bidang jasa dan produk untuk kendaraan alat berat (Heavy Duty Equipment) dan juga penyedia jasa kebutuhan alat berat (Heavy Mobile Equipment Solutions) yang beralamat di Kota Tangerang. Pada PT Multipedia Teknika Indonesia terdapat beberapa departemen yang terbagi sesuai dengan struktur perusahaan, sebagaimana yang terdapat pada perusahaan lainnya, setiap departemen perusahaan akan melakukan suatu pengajuan rencana anggaran / budget untuk menjalankan berbagai kegiatan operasional seharihari, sehingga setiap departemen diharuskan untuk melakukan proses pengajuan rencana anggaran dengan tepat untuk digunakan nantinya.

Sejalan dengan perkembangan teknologi informasi yang semakin pesat banyak perusahaan yang sudah menggunakan sistem terkomputerisasi dalam kegiatan pengajuan rencana anggaran atau budgeting pada perusahaan mereka. Namun, pada PT Multipedia Teknika Indonesia proses pengajuan serta penggunaan anggaran / budget dengan sistem terkomputerisasi ini belum diterapkan. Proses pengajuan dan penggunaan budget masih menggunakan sistem semi-komputerisasi, dimana saat melakukan pengajuan maupun penggunaan budget masih menggunakan Ms. Excel yang kemudian akan diteruskan kepada pihak terkait melalui surel. Sistem ini dirasa belum cukup efektif, baik dalam proses pengolahan data (berisiko terjadinya human error) maupun dalam kegiatan monitoring budget. Akibat dari kelemahan pada sistem yang sedang berjalan, tentunya PT Multipedia Teknika Indonesia membutuhkan suatu sistem yang terkomputerisasi dalam proses budgeting. Dengan adanya sistem yang terkomputerisasi ini diharapkan dapat meminimalisir terjadinya risiko human error, serta mempermudah pihak terkait untuk melakukan monitoring budget.

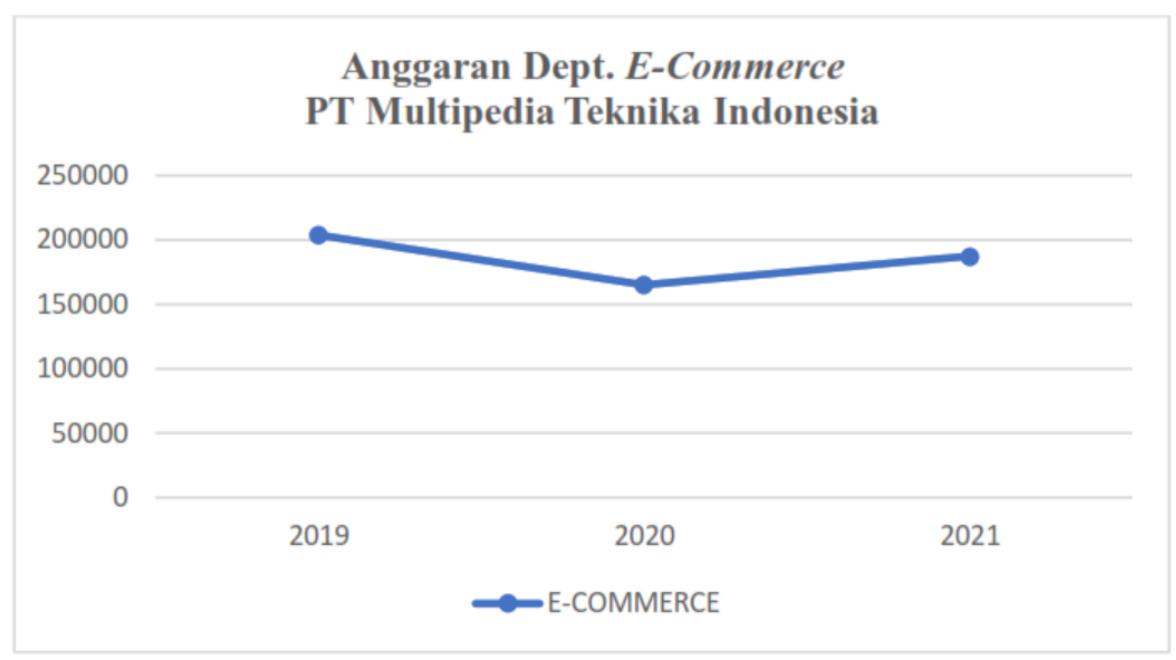

Gambar 1

Grafik Penganggaran pada dept. e-commerce PT Multipedia Teknika Indonesia Sumber : PT Multipedia Teknika Indonesia

Masalah yang dihadapi oleh PT Multipedia Teknika Indonesia antara lain Proses pengajuan budget list dan penggunaan budget masih dilakukan secara semi-komputerisasi dengan Ms. Excel dengan persetujuan yang memakan waktu cukup lama. Karena pencatatan jumlah sisa saldo budget masih dilakukan dengan Ms. Excel, maka rentan terjadi selisih pencatatan antara admin departemen dengan 
admin finance dan mengharuskan kedua pihak melakukan pengecekan ulang. Disamping itu Laporan ketersediaan anggaran dan laporan atas penggunaan anggaran yang dihasilkan pun sering terjadi selisih akibat pembuatan laporan yang masih menggunakan Ms. Excel.

Menurut Ningsih, dkk. (2018:22) Konsep e-budgeting merupakan pengembangan konsep budgeting, salah satu financial tools di dalam mengelola suatu perusahaan maupun pemerintah. Ebudgeting adalah aplikasi teknologi informasi atau perangkat lunak untuk mendukung siklus, mulai dari perencanaan, pembuatan program, sampai dengan kendali dan evaluasi. Penelitian yang pernah dilakukan mengenai e-budgeting pernah dilakukan oleh Setyawan, dkk. (2017) dalam menganalisis kemampuan desa untuk mengelola dana desa dan mengembangkan lebih lanjut e-budgeting dan sistem pelaporan elektronik untuk mencapai efisiensi alokasi dana desa di Desa Bale Sari. Hasil penelitian menunjukkan bahwa Pemerintah Kabupaten Magelang menyusun e-budgeting dalam kegiatan anggaran. Dengan mempercepat proses penganggaran kegiatan mulai dari perencanaan, penganggaran hingga pengendalian anggaran dapat membantu mewujudkan efisiensi dana desa dan mengurangi penyelenggaraan pemerintahan desa balesari. Sementara oleh Erlina, dkk melakukan penelitian yang bertujuan untuk mengidentifikasi faktor-faktor utama yang mempengaruhi kualitas anggaran di Kota Medan, Indonesia. Penelitian tersebut mendapatkan hasil atas pendekatan kualitatif yaitu ada beberapa faktor lain yang mempengaruhi keputusan pembiayaan pemerintah, antara lain faktor sosial, perubahan demografi, faktor hukum dan faktor antar pemerintah itu sendiri.

\section{Metode Penelitian}

Dalam melakukan penelitian, terdapat beberapa tahapan sehingga dapat memberikan solusi atas masalah yang dihadapi saat ini. Tahapan penelitian disajikan melalui gambar dibawah ini :

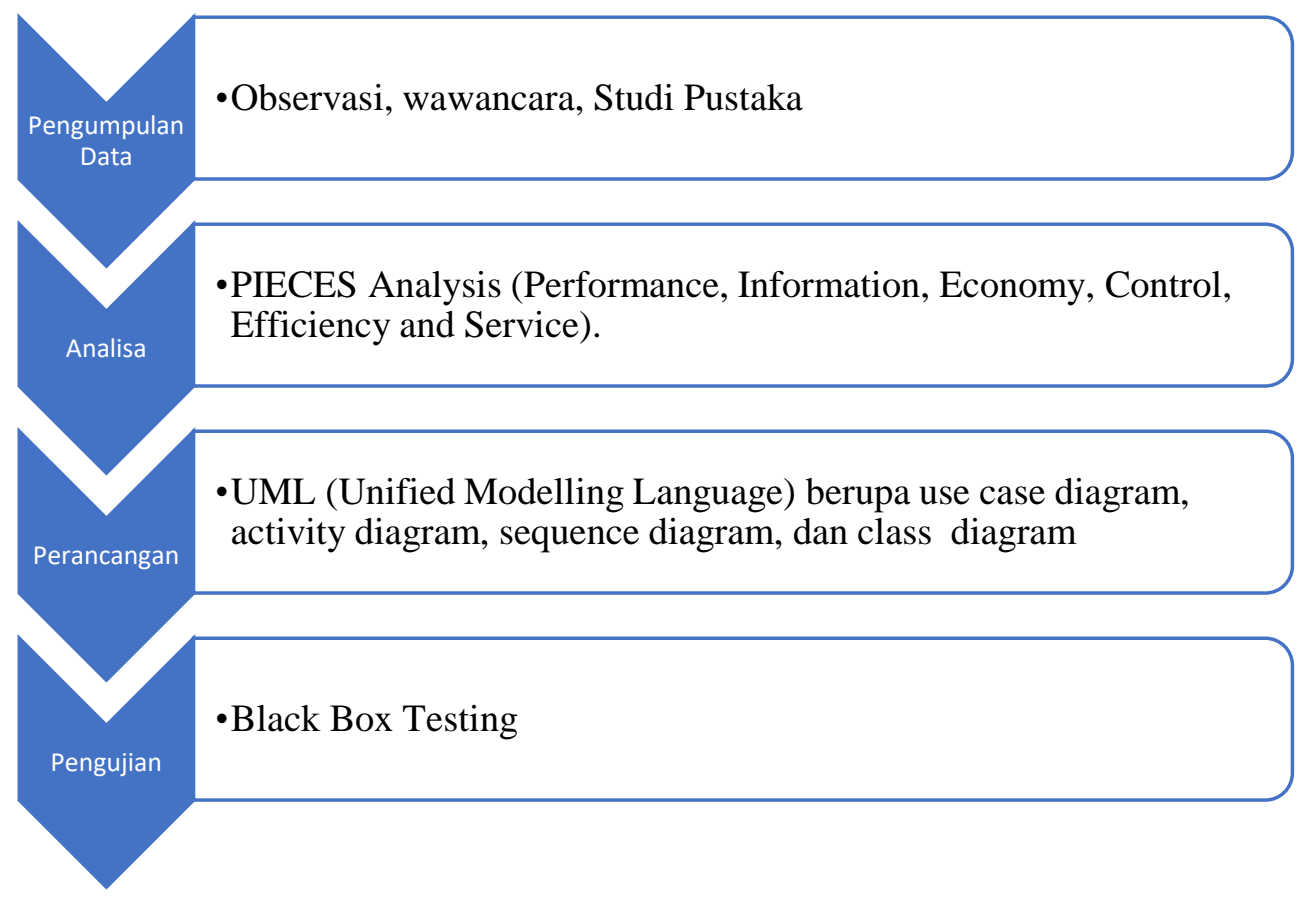

\section{Gambar 2. Tahapan Penelitian}

Pengumpulan data untuk memperoleh informasi yang dibutuhkan dalam rangka mencapai tujuan penelitian dilakukan melalui tahapan berikut ini :

\section{Pengumpulan Data}

a. Observasi

Dilakukan melalui pengamatan langsung dan mencatat secara sistematis terhadap objek yang diteliti. Observasi dilakukan pada PT. Multipedia Teknika Indonesia dengan cara 
pengamatan dan pengambilan beberapa data yang diperlukan sesuai dengan topik penelitian

b. Wawancara

Dilakukan dengan cara mengajukan beberapa pertanyaan secara langsung untuk mendapatkan data atau informasi yang terperinci tentang sistem budgeting PT. Multipedia Teknika Indonesia. Wawancara dilakukan bersama Ibu Wati, selaku admin PT Multipedia Teknika Indonesia.

c. Studi Pustaka

Merupakan kegiatan menghimpun informasi yang relevan dengan topik atau masalah yang menjadi objek penelitian. Dapat diperoleh dari buku-buku, karya ilmiah, tesis, disertasi, ensiklopedia, internet dan sumber-sumber lain.

2. Metode Analisa

Pada tahap ini menggunakan PIECES sebagai metode analisanya. Metode ini dianggap mampu untuk mendapatkan dan mengedintifikasi pokok-pokok permasalahan yang lebih spesifik. Yaitu dengan mengukur jumlah produksi dan waktu tanggap, Analisa terhadap kemampuan dari sistem informasi, analisa mengenai segala sesuatu yang berkaitan mengenai persoalan ekonomi, Analisa untuk meningkatkan kinerja sistem, mencegah atau mendeteksi kesalahan dari sistem, menjamin keamanan dan kerahasiaan data. serta menghasilkan output atau keluaran yang sebanyak-banyaknya dengan input seminimal mungkin. Karena jika input dilakukan secara berlebihan akan membuat sistem tidak berjalan dengan efisien. sekaligus menilai suatu sistem mengenai layanan yang disediakan atau diberikan oleh system

3. Metode Perancangan

Pada tahap ini menggunakan UML (Unified Modelling Language) yang digambarkan menggunakan Visual Paradigm, UML yang digambarkan berupa use case diagram, activity diagram, sequence diagram, dan class diagram.

4. Metode Pengujian

Peda tahap ini dilakukan dengan mengamati hasil eksekusi melalui data uji dan memeriksa fungsional dari perangkat lunak. Uji coba Black Box dilakukan dengan membandingkan apakah hasil program sudah sesuai dengan yang diharapkan, untuk mencari kesalahan fungsi dari program.

\section{Hasil dan Pembahasan}

Penelitian ini dilakukan pada PT Multipedia Teknika Indonesia, yang merupakan perusahaan yang bergerak dalam bidang Heavy Duty dan Automotive. Perusahaan ini telah memberikan solusi kepada beberapa Customer sektor industri diantaranya Highway, Offroad, Pertambangan, Otomotif, Perkakas, Lighting and Accessories, Mesin, Back Up Alarm, dll.

Berdasarkan hasil analisis yang didapat dalam menemukan permasalahan yang dihadapi oleh PT Multipedia Teknika Indonesia, maka beberapa alternatif pemecahan masalah yang diusulkan adalah sebagai berikut :

1. Pada proses pengajuan budget list dan pengajuan penggunaan budget, dibutuhkan sistem untuk mempermudah dan mempercepat prosedur persetujuan.

2. Diperlukan sistem yang dapat menampilkan saldo sisa anggaran secara realtime untuk mempermudah saat monitoring budget.

3. Diperlukan sistem yang dapat dengan otomatis mencatat dan menghasilkan laporan atas budget yang disetujui beserta penggunaannya.

Dari alternatif pemecahan masalah diatas, dapat dibuat system usulan dengan menggunakan aplikasi berbasis web dengan hak akses yang dapat dilakukan oleh masing-masing pengguna dalam system. Berikut ini disajikan perbedaan system yang sedang berjalan saat ini dengan system yang diusulkan. 
Tabel 2. Perbedaan Sistem Berjalan dan Sistem Usulan

\begin{tabular}{|c|l|l|}
\hline No. & Sistem Berjalan & Sistem Usulan \\
\hline 1. & $\begin{array}{l}\text { Pengajuan budget masih dilakukan dengan } \\
\text { semi komputerisasi melalui surel memicu } \\
\text { human error hingga manipulasi data }\end{array}$ & $\begin{array}{l}\text { Sistem informasi e-budgeting berbasis web } \\
\text { yang diusulkan dapat memudahkan dalam p } \\
\text { roses pengajuan budget }\end{array}$ \\
\hline 2. & $\begin{array}{l}\text { Pencatatan saldo budget masih } \\
\text { menggunakan Ms. Excel memicu selisih } \\
\text { data antara finance dengan admin, sehingga } \\
\text { membutuhkan pengecekan secara berulang }\end{array}$ & $\begin{array}{l}\text { Sistem informasi e-budgeting yang diusulkan, } \\
\text { pencatatan hingga sisa saldo terupdate dapat } \\
\text { dilihat secara realtime }\end{array}$ \\
\hline 3. & $\begin{array}{l}\text { Pembuatan laporan berdasarkan file excel } \\
\text { memicu kesalahan akibat human error }\end{array}$ & $\begin{array}{l}\text { Sistem informasi e-budgeting yang diusulkan } \\
\text { menyediakan laporan budget acc, laporan } \\
\text { penggunaan budget, hingga laporan } \\
\text { pembayaran }\end{array}$ \\
\hline
\end{tabular}

Berdasarkan analisis atas penelitian yang dilakukan pada sistem budgeting. Saat ini menghasilkan beberapa perubahan pada sistem yang diusulkan, salah satunya manajer akan dimudahkan saat proses pengajuan budget kepada direktur tanpa harus mengirim surel, dan admin dapat mengajukan penggunaan budget dengan lebih mudah pada sistem tersebut, laporan pun akan tersedia secara realtime.

Spesifikasi sistem yang diusulkan disusun dalam bentuk elisitasi yang berisi sekumpulan aktivitas yang ditujukan untuk menemukan kebutuhan suatu sistem, dan pihak lain yang memiliki kepentingan dalam pengembangan system.

\section{Tabel 2. Spesifikasi Kebutuhan yang Diusulkan}

\begin{tabular}{|c|l|}
\hline No & Keterangan \\
\hline 1 & Menampilkan halaman login yang berisi username dan password \\
\hline 2 & Terdapat fasilitas untuk upload foto pengguna \\
\hline 3 & Terdapat identitas pengguna \\
\hline 4 & Dapat melakukan pengajuan budget \\
\hline 5 & Dapat melakukan transaksi penggunaan budget \\
\hline 6 & Dapat melakukan ubah saldo budget \\
\hline 7 & Menampilkan menu laporan penggunaan budget \\
\hline 8 & Menampilkan menu laporan budget \\
\hline 9 & Menampilkan menu saldo budget \\
\hline 10 & Menampilkan menu akun budget \\
\hline 11 & Menampilkan menu persetujuan budget \\
\hline 12 & Dapat melakukan cetak laporan budget \\
\hline 13 & Dapat melakukan cetak laporan penggunaan budget \\
\hline 14 & Dapat menghapus akun pengguna \\
\hline 15 & Dapat mencari data pembayaran sesuai tanggal dilakukannya \\
\hline 16 & Menampilkan pilihan menu sesuai hak akses \\
\hline
\end{tabular}

Dalam perancangan sistem usulan, peneliti menggunakan UML (Unified Modelling Language) sebagai media ilustrasi dalam bentuk diagram. Use case diagram disajikan melalui gambar berikut : 


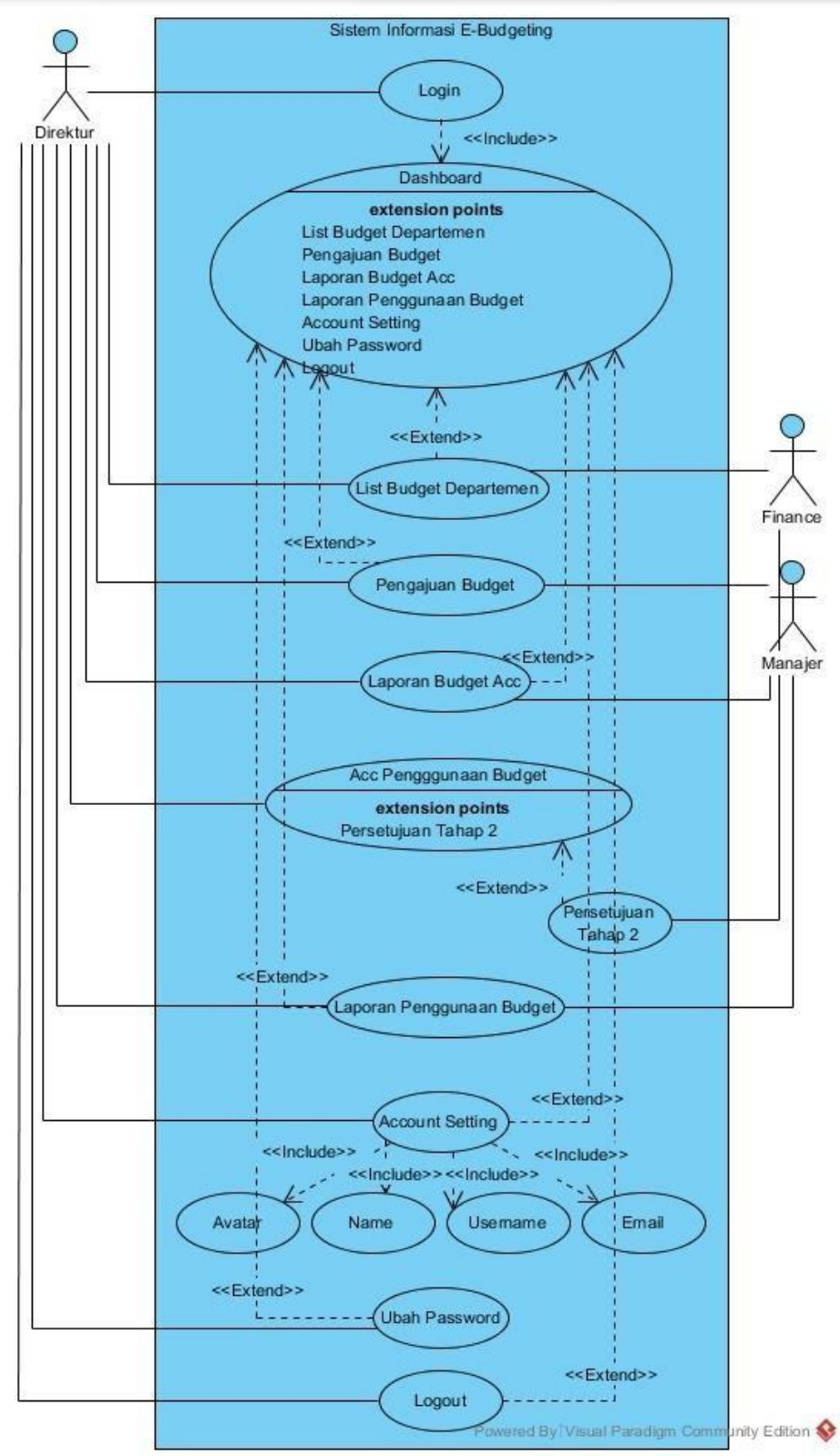

Gambar 3. Use Case diagram sistem usulan

Dari diagram diatas dapat dijelaskan sebagai berikut :

a. user dapat melakukan login.

b. Dapat menampilkan beberapa menu pada sistem, seperti dashboard, list budget departemen, pengajuan budget, acc penggunaan budget, laporan penggunaan budget, dan laporan budget acc.

c. Dapat melakukan persetujuan maupun penolakan untuk melakukan penyesuaian budget pada menu pengajuan budget yang telah dilakukan oleh manajer.

d. Dapat memberikan persetujuan pada menu Acc Penggunaan Budget sebagai persetujuan tahap 2.

e. Dapat melihat dan mencetak laporan penggunaan budget dan laporan budget acc dalam bentuk pdf.

f. apat mengakses menu account setting yang berfungsi untuk mengubah avatar, nama, username, dan email pada sistem.

g. Dapat mengubah password yang digunakan pada sistem pada menu ubah password 


\section{Analisa PIECES}

Tahapan analisis terhadap suatu sistem merupakan hal yang paling kritis dalam menganalisa sebuah sistem, karena dengan menganalisis suatu masalah / hambatan / kendala dapat diketahui. Tahap analisis harus dilakukan sebelum melakukan perancangan terhadap sebuah sistem. Metode analisis yang digunakan adalah metode PIECES, seperti yang digambarkan sebagai berikut :

Tabel 2. Hasil Analisis PIECES

\begin{tabular}{|c|c|}
\hline $\begin{array}{r}\text { Parameter } \\
\end{array}$ & $\begin{array}{r}\text { Parameter } \\
\end{array}$ \\
\hline Kinerja (Performance) & $\begin{array}{l}\text { Saat melakukan penginputan data, masih sering } \\
\text { terjadi kesalahan seperti perbedaan laporan } \\
\text { antara admin departemen dengan admin finance }\end{array}$ \\
\hline Informasi (Information) & $\begin{array}{l}\text { Belum tersedianya jumlah sisa budget yang ter- } \\
\text { update antara pihak-pihak terkait. }\end{array}$ \\
\hline Ekonomi (Economy) & $\begin{array}{l}\text { Semakin banyak waktu yang digunakan semakin } \\
\text { banyak juga biaya yang dikeluarkan untuk } \\
\text { keperluan memberikan gaji kepada pegawai. }\end{array}$ \\
\hline Kontrol (Control) & $\begin{array}{l}\text { Pengontrolan 29ystem masih termasuk lemah } \\
\text { dikarenakan untuk mengetahui laporan } \\
\text { penggunaan budget, pihak } \\
\text { terkait masih harus mengecek manual melalui } \\
\text { Microsoft Excel dan rentan terjadi human error. }\end{array}$ \\
\hline Efisiensi (efficiency) & $\begin{array}{l}\text { Pengerjaan yang dilakukan oleh admin } \\
\text { departemen dan admin finance dalam file } \\
\text { Microsoft Excel yang terpisah dapat } \\
\text { menyebabkan perbedaan atau selisih dalam } \\
\text { menghasilkan laporan }\end{array}$ \\
\hline Pelayanan (Service) & $\begin{array}{l}\text { Sistem yang berjalan saat ini belum } \\
\text { mempermudah manajer dalam mengajukan } \\
\text { budget list dan belum dapat menampilkan saldo } \\
\text { budget secara real-time yang mempersulit } \\
\text { pengontrolan budget. }\end{array}$ \\
\hline
\end{tabular}

\section{Implementasi Sistem}

Setelah dilakukan Analisa kebutuhan sistem yang dituangkan dalam bentuk elisitasi, selanjutnya adalah membangun sistem sesuai dengan kebutuhan stakeholder. Sistem yang dibangun adalah sistem informasi e-budgeting berbasis web dengan menggunakan bahasa pemrograman PHP dan database MySQL. Sistem dibangun dengan menggunakan framework codeigniter dengan hak akses terdiri dari 4 hak akses yaitu Manajer, Direktur, Admin dan Finance. Keempat hak akses tersebut diberikan sesuai dengan kewenangan dan kebutuhan penggunaan aplikasi. Berikut tampilan antar muka yang diusulkan .

\section{Form Login}

Untuk masuk kedalam system informasi e-budgeting, pengguna harus lebih dulu login dengan username dan password yang sudah diberikan oleh admin. Sistem akan otomatis memvalidasi apakah username dan password yang dimasukkan benar. Tahap ini juga yang menentukan seorang pengguna memiliki hak akses tertentu. Jika berhasil login maka pengguna akan diarahkan ke dalam system dengan menu yang sesuai dengan hak akses masing-masing. Tampulan form login disajikan pada gambar dibawah ini. 


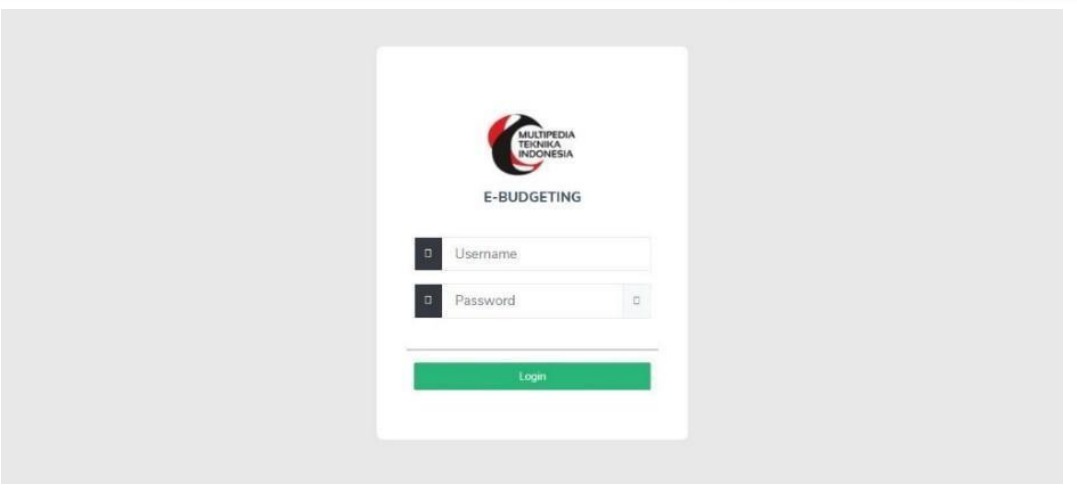

Gambar 4. Form Login Pengguna

\section{Pengajuan Budet}

Sebelum melakukan input pengajuan budget, seorang manajer harus membuat budget list yang dibutuhkan oleh departemennya. Pengajuan penggunaan budget dilakukan oleh admin pada setiap departemen. Untuk melakukan pengajuan, pengguna dapat menekan tombol tambah pengajuan untuk kemudian melengkapi field-field yang dibutuhkan. Tampilan data penggunaan budget disajikan pada gambar dibawah ini :

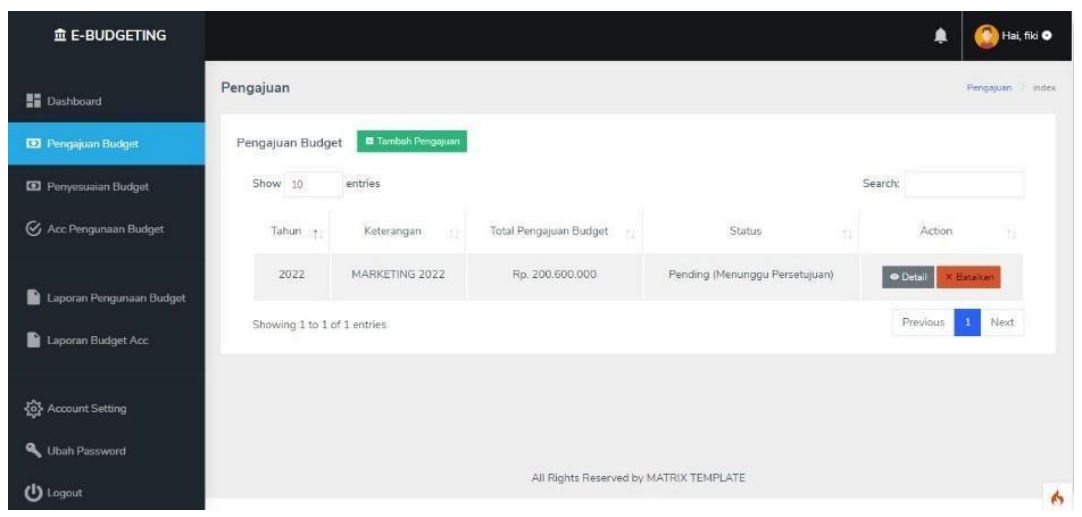

Gambar 5. Pengajuan Budget

\section{Penggunaan Budget}

Setelah pengajuan budget disetujui, selanjutnya department yang mengajukan melakukan input penggunaan budget. Besaran penggunaan budget harus sesuai dengan budget yang diajukan. Apabila pengeluaran budget lebih besar dari budget yang diajukan, maka system otomatis akan menolak dan meminta pengguna untuk melakukan penyesuaian penggunaan budget.

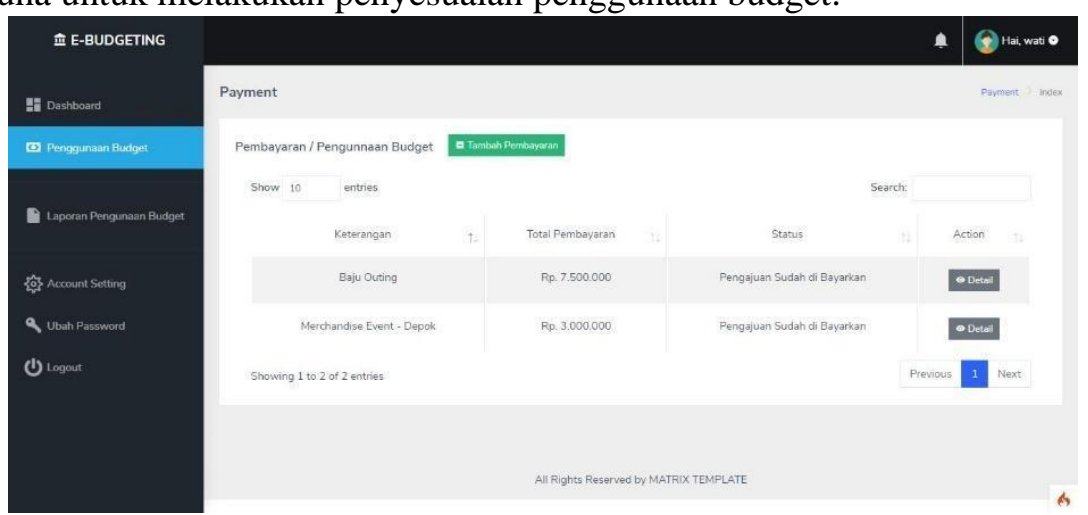

Gambar 6. Penggunaan Budget 


\section{Laporan Penggunaan Budget}

Setelah pengajuan budget disetujui dan melakukan penyesuaian budget. Seluruh pengunaan budget tersebut akan tersimpan dalam database, sehingga akan lebih mudah dalam penyampaian laporan. Berikut ini adalah tampilan dari menu laporan penggunaan budget.

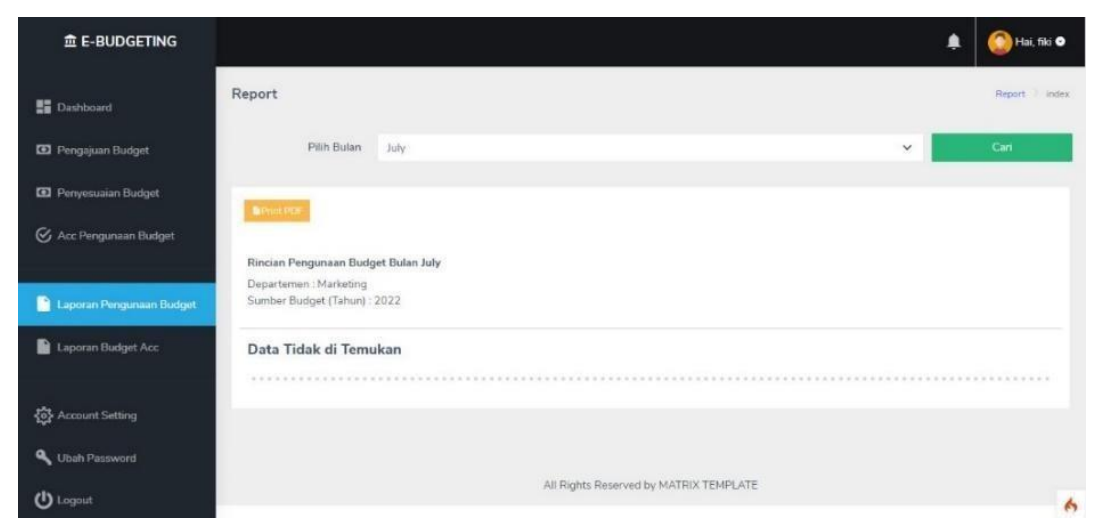

Gambar 7. Laporan penggunaan budget

\section{Pengujian Aplikasi}

Pengujian dilakukan menggunakan metode black box testing guna memastikan hasil eksekusi dan kesalahan fungsionalitas program pada sistem. pengujian hanya membahas sisi luar suatu aplikasi perangkat lunak, dimana mulai dari tampilan hingga aksi input dalam strategi testing. Untuk menemukan kesalahan-kesalahan dalam beberapa kategori diantaranya kesalahan fungsi, kesalahan interface, kesalahan dalam struktur data/akses database eksternal, kesalahan performa, kesalahan inisialisasi dan terminasi Dengan hasil pengujian black box testing pada sistem seperti berikut.

\section{Tabel 3. Daftar pengujian dengan Black Box Testing}

\begin{tabular}{|c|l|}
\hline No. & Skenario Pengujian \\
\hline 1 & Login Sistem Informasi e-budgeting \\
\hline 2 & Input Pengajuan Budget \\
\hline 3 & Input Penggunaan Budget \\
\hline 4 & Ubah Password \\
\hline
\end{tabular}

Untuk dapat masuk ke dalam sistem informasi e-budgeting, setiap user harus melakukan login terlebih dahulu. Pengujian ini dilakukan dengan beberapa skenario seperti berikut :

Tabel 4 Pengujian Login Sistem Informasi e-budgeting

\begin{tabular}{|l|l|c|l|l|l|}
\hline No & Skenario Pengujian & Test Case & $\begin{array}{l}\text { Hasil yang } \\
\text { diharapkan }\end{array}$ & $\begin{array}{l}\text { Hasil } \\
\text { Pengujian }\end{array}$ & Kesimpulan \\
\hline 1 & $\begin{array}{l}\text { Login dengan mengisi } \\
\text { username yang salah atau } \\
\text { tidak terdaftar }\end{array}$ & $\begin{array}{l}\text { Sistem akan } \\
\text { menolak akses } \\
\text { Login dengan } \\
\text { menampilkan } \\
\text { "User Tidak } \\
\text { ditemukan } \\
\text { atau User } \\
\text { TidakAktif! }\end{array}$ & & Valid \\
\hline
\end{tabular}




\begin{tabular}{|c|c|c|c|c|}
\hline 2 & $\begin{array}{l}\text { Input data Pengajuan } \\
\text { budget dengan tahun } \\
\text { budget yang sama }\end{array}$ & 望 & $\begin{array}{l}\text { Sistem akan } \\
\text { Menolak } \\
\text { pengajuan } \\
\text { budget dengan } \\
\text { keterangan } \\
\text { "Tahun } \\
\text { Pengajuan } \\
\text { Budget Sudah } \\
\text { Ada!" }\end{array}$ & Valid \\
\hline 3 & \begin{tabular}{lr}
\multicolumn{2}{l}{ Input data penggunaan } \\
budget r & dengan \\
mengosongkan salah satu \\
kolom & (Keterangan, \\
keterangan pembayaran, \\
nomor rekening \\
pembayaran, atau jumlah \\
pembayaran)
\end{tabular} & $=$ & $\begin{array}{l}\text { Sistem akan } \\
\text { menolak } \\
\text { penggunaan } \\
\text { budget dengan } \\
\text { keterangan } \\
\text { "Pengajuan } \\
\text { Gagal, Harap } \\
\text { Mengisi } \\
\text { Informasi } \\
\text { dengan } \\
\text { Benar!" }\end{array}$ & Valid \\
\hline 4 & $\begin{array}{l}\text { Penggantian password } \\
\text { dengan kesalahan } \\
\text { mengisi password lama }\end{array}$ & & $\begin{array}{l}\text { Sistem akan } \\
\text { Menolak } \\
\text { penggantian } \\
\text { password } \\
\text { dengan } \\
\text { keterangan } \\
\text { "Password } \\
\text { Lama yang } \\
\text { Anda } \\
\text { Masukkan } \\
\text { Salah!"' }\end{array}$ & Valid \\
\hline
\end{tabular}

\section{Kesimpulan}

Berdasarkan hasil analisis terhadap sistem budgeting pada PT Multipedia Teknika Indonesia, maka dapat disimpulkan bahwa Proses budgeting yang berjalan pada PT Multipedia Teknika Indonesia saat ini masih semi-komputerisasi sehingga menimbulkan selisih saldo sehingga membutuhkan pengecekan secara berulang. Saat pembuatan laporan pun masih rentan akan kesalahan akibat data yang selisih maupun human error. sistem informasi e-budgeting yang diusulkan diharapkan pihak-pihak terkait akan merasa dimudahkan dalam proses pengajuan maupun penggunaan budget, dapat meminimalisir kelemahan, serta membuat proses budgeting pada PT Multipedia Teknika Indonesia menjadi lebih efektif dan efisien dibandingkan sistem sebelumnya

\section{Daftar Pustaka}

[1]. Hidayat, T., \& Muttaqin, M. (2018). Pengujian sistem informasi pendaftaran dan pembayaran wisuda online menggunakan black box testing dengan metode equivalence partitioning dan boundary value analysis. Jurnal Teknik Informatika UNIS, 6(1), 25-29.

[2]. Ningsih, Virgiana, Ria Nelly Sari, and Muhammad Rasuli. Analisis Penerapan E-Planning Dan E-Budgeting Pada Pemerintah Daerah (Studi Kasus Pada Pemerintah

[3]. Kabupaten Bengkalis) Jurnal Ekonomi 26.2 (2018): 18-31. 
[4]. Setyawan, Supanji, Nuwun Priyono, and Chaidir Iswanaji. Development model of e-budgeting and e-reporting system on the management of village fund finance. Jurnal Dinamika Akuntansi 9.1 (2017): 92-99.

[5]. Nurjamiah, Arie Rafika Dewi. Aplikasi Pengelolaan Keuangan Melalui E-Village Budgeting Sebagai Sarana Transparansi Pengelolaan Keuangan. Journal of Information System Research (JOSH) 1.2 (2020): 7781.

[6]. Soleh, Angga Nurcahyanto. Analisa Sistem Informasi E-Budgeting Pengajuan Rencana Anggaran Perusahaan menggunakan Balance Scorecard. SINDIMAS 1.1 (2019): 260-264. 